\title{
ANALISIS MANAJEMEN PENGELOLAAN LIMBAH MEDIS DI RUMAH SAKIT TNI AL SAMUEL J. MOEDA KUPANG
}

\author{
${ }^{1}$ Yanik Tri Lestari dan ${ }^{2}$ Erny Ernawati Pua Upa \\ ${ }^{1}$ Rumah Sakit TNI AL Samuel J. Moeda Kupang \\ ${ }^{2}$ Program Studi Ilmu Kesehatan Masyarakat, FKM-Undana
}

\begin{abstract}
ABSTRAK
$\mathrm{R}$ umah sakit merupakan instansi pelayanan kesehatan yang setiap harinya akan menghasilkan limbah medis, terutama limbah medis padat perlu dikelola dengan baik. Rumah Sakit TNI AL Samuel J. Moeda Kupang telah melaksanakan pengelolaan limbah medis padat, namun belum dilakukan secara baik. Hal ini terlihat dari sumber daya tenaga pengelola yang masih kurang dan proses pengelolaan yang masih seadanya serta belum tersedianya alat pengelolaan akhir yaitu incenerator. Tujuan penelitian ini untuk mengetahui manajemen pengelolaan limbah medis mulai dari input, proses, dan output. Jenis penelitian ini adalah survey deskriptif dengan pendekatan kualitatif. Jenis data yang digunakan yaitu data primer yang di peroleh dari wawancara dan observasi langsung, sedangkan data sekunder diperoleh dari dokumen yang ada. Hasil penelitian menunjukkan bahwa tahap input belum optimal, dimana kualifikasi pendidikan tenaga pengelola limbah medis padat belum sesuai, sarana prasarana limbah medis padat masih kurang dan terbatas, dan juga dana yang belum tercukupi dan terperinci. Hasil penelitian juga menunjukkan bahwa pada aspek proses pengelolaan limbah medis padat di RS TNI AL Samuel J. Moeda Kupang belum dilakukan secara optimal dan masih ditemukan kesalahan. Begitu juga dengan output pengelolaan limbah medis padat belum sesuai standar Kepmenkes No.1204 tahun 2004, dimana pengelolaan limbah medis padat belum terkelola dengan baik dan tuntas. Terjadinya masalah-masalah tersebut karena pengelolaan limbah kurang mendapat perhatian dari pihak rumah sakit sehingga perlu dilakukan perekrutan, pendidikan dan pelatihan tenaga pengelola limbah medis rumah sakit, serta adanya evaluasi pengelolaan limbah secara berkala agar tercipta lingkungan rumah sakit yang sehat.
\end{abstract}

Kata Kunci $\quad$ : Manajemen Pengelolaan, Limbah Medis Padat, Rumah Sakit 


\author{
MANAGEMENT'S STUDY OF WASTE MANAGEMEN \\ IN SAMUEL J. MOEDA NAVAL BASE HOSPITAL IN KUPANG \\ ${ }^{1}$ Yanik Tri Lestari dan ${ }^{2}$ Erny Ernawati Pua Upa \\ ${ }^{1}$ Hospital TNI AL Samuel J. Moeda Kupang \\ ${ }^{2}$ Public Helath Program Study, FKM-Undana
}

\begin{abstract}
$\mathrm{H}$ ospital is a health service institution that produces daily medical waste, particularly solid medical waste that needs to be managed properly. The navy hospital of Samuel J. Moeda Kupang has implemented solid medical waste management, yet it has not been done well. It was clearly seen from the lack of human resource and its less improved management process as well as the absence of final processing tool that is incenerator. The aim of this research is to get know of the medical waste management starting from input, process, and output. The type of research is descriptive survey with qualitative approach. The data used consist of primary data obtained from interview and direct observation and secondary data obtained from the existing documents. The result of this research indicated that the input stage has not been optimal because the education qualification of the waste management employee has not been appropriate, the infrastructure of solid medical waste has been lacked and limited, and the fund has not been fulfilled and detailed. This result also showed that at the process stage, solid medical waste management in the Navy Hospital of Samuel J. Moeda Kupang has not been executed optimally and has got many flaws. So as the output stage, solid medical waste management has not been managed properly and thoroughly. Those problems occurred due to less attention of the hospital management towards waste management so that it needed more recruitment as well as training and education for medical waste management employee, more over it required a periodic evaluation of waste management in order to create a healthy hospital environment.
\end{abstract}

Keywords $\quad$ : Management, Solid Medical Waste, Hospital 


\section{PENDAHULUAN}

Rumah Sakit (RS) TNI Angkatan Laut Samuel J. Moeda Kupang merupakan salah satu rumah sakit yang berada di Kupang denga tipe $C$ yang sampai saat ini belum terakreditasi artinya RS TNI AL mempunyai fasilitas dan kemampuan pelayanan medis spesialistik luas dan pelayanan penunjang klinis. Data yang di dapat dari Rumah Sakit TNI AL Samuel J. Moeda Kupang menunjukkan bahwa, volume limbah medis padat dan non medis yang dihasilkan pada tahun 2013 sampai 2016 mengalami peningkatan dari tahun ke tahun dapat di lihat pada Tabel 1.

Tabel 1. Data Tahunan Volume Limbah Medis Padat dan Non Medis di RS TNI AL Samuel J. Moeda Kupang

\begin{tabular}{cccc}
\hline & & \multicolumn{2}{c}{ Limbah Padat $(\mathrm{Kg})$} \\
\cline { 3 - 4 } No. & Tahun & Medis & Non Medis \\
\hline 1. & 2013 & 548 & 1.440 \\
2. & 2014 & 908 & 1.823 \\
3. & 2015 & 1.359 & 2.434 \\
4. & 2016 & 1.404 & 2.592 \\
\hline
\end{tabular}

Sumber : Laporan Tahunan Rumah Sakit TNI AL Samuel J. Moeda

Tabel 2. Data Tahunan Kunjungan Pasien di RS TNI AL Samuel J. Moeda Kupang

\begin{tabular}{ccc}
\hline Jumlah Kunjungan & Rawat Inap & Rawat Jalan \\
\hline 2013 & 996 & 7.440 \\
2014 & 1.512 & 9.720 \\
2015 & 1.692 & 11.976 \\
2016 & 2.412 & 14.448 \\
\hline
\end{tabular}

Sumber : Laporan Tahunan Rumah Sakit TNI AL Samuel J. Moeda

Hasil penelusuran sementara dari beberapa karyawan yang mengurusin limbah medis rumah sakit yang diwawancarai ditemukan bahwa hampir sebagian besar dari mereka belum mengetahui jenis - jenis limbah yang ada di rumah sakit baik itu limbah medis padat maupun limbah medis cair dan jenis - jenis plastik yang digunakan dalam pewadahan pada limbah medis padat serta belum mengetahui standar incenerator yang baik untuk pembakaran limbah medis padat serta persyaratan yang harus dimiliki oleh Instalasi Pengolahan Air Limbah (IPAL) 
Pengolahan limbah medis cair di RS TNI Angkatan Laut Samuel J. Moeda Kupang sudah menggunakan metode IPAL. Sejak tahun 2013 dan telah mendapatkan izin dari Kementerian Lingkungan Hidup untuk mengoperasikan IPAL tersebut. Namun karena keterbatasan SDM sehingga sampai sekarang belum terkelola dengan baik, itu dibuktikan dengan tidak adanya tenaga yang kualifikasi Kesling sebagai penanggungjawab limbah medis di rumah sakit dan bukti lain bahwa hasil olahan dari IPAL tersebut tidak bisa difungsikan seperti untuk air kolam ikan karena bisa menyebabkan ikan kolam mati. Kondisi di atas sangat berpengaruh pada adanya peningkatan infeksi nosokomial dari tahun 2015 terdapat 4 kasus sedangkan pada tahun 2016 menjadi 7 kasus infeksi nosokomial. Fakta tersebut merupakan salah satu indikasi adanya masalah baik hygiene perorangan maupun sanitasi lingkungan, proses yang tidak memperhatikan keamanan petugas dan warga rumah sakit serta kondisi tempat penampungan sampah/limbah sementara kurang memadai. Selain itu, komitmen dari manajemen rumah sakit juga masih lemah dalam menyelesaikan permasalahan limbah medis. Mereka lebih cenderung memperhatikan pelayanan yang berhubungan langsung kepada pasien.

\section{METODE PENELITIAN}

Pendekatan kualitatif yaitu menganalisis beberapa variabel yang di teliti antara lain karakteristik limbah medis (jenis dan sumber), upaya minimalisasi limbah medis yang telah dilakukan oleh RS TNI Angkatan Laut Samuel J. Moeda Kupang meliputi reduksi limbah pada sumbernya dan pemanfaatan limbah medis, serta proses pengelolaan limbah medis dari tahap pemilahan hingga pemusnahan limbah medis. Selain itu, penelitian ini juga dilengkapi dengan pendekatan kuantatif yakni dengan menggunakan metode perhitungan untuk mengetahui jumlah timbulan limbah medis.

Penelitian ini dilakukan di Rumah Sakit TNI Angkatan Laut Samuel J. Moeda Kupang jln. Yos Sudarso No.05 Kel. Namosain Kec. Alak, Kota Kupang. Pelaksanaan penelitian ini membutuhkan waktu selama satu bulan terhitung Januari 2017 sampai Februari 2017. Instrumen yang digunakan untuk pengumpulan data primer berupa panduan wawancara mendalam yang berisi pertanyaan terbuka untuk mendapatkan informasi yang mendalam. untuk menjaga keakuratan hasil yang diperoleh dengan menggunakan alat perekam dan alat tulis. 
Lembaran check list untuk panduan dalam observasi di lapangan, serta kuesioner sebagai panduan wawancara singkat dengan cleaning service sedangkan untuk data sekunder menggunakan panduan telaah dokumen dan hardcopy dari dokumen-dokumen terkait mengenai sistem pengelolaan limbah medis.

\section{HASIL DAN BAHASAN}

\section{Aspek Legalitas}

Hasil wawancara diketahui bahwa sampai saat ini pengolahan air limbah rumah sakit sudah kadaluarsa dan belum diperbaharui termasuk pengolahan limbah medis padat (incenerator ) belum mengantongi ijin, disamping itu pemeriksaan sampel berkala untuk air limbah rumah sakit tidak diperiksakan secara berkala sehingga proses perpanjangan perijinan IPAL dan incenerator terkendala. Belum adanya Standar Operasional Prosedur (SOP) untuk pengolahan limbah, baik itu pengolahan limbah medis cair maupun limbah medis padat, termasuk standar untuk APD juga belum ada hal ini mengingat limbah medis termasuk yang berbahaya. Berikut kutipan wawancara dengan Direktur RS TNI AL Kupang :

" Kalau masalah ijin pengolahan air limbah kita sudah pernah dapat tapi hanya berlaku 2 tahun aja karena memang mestinya harus di perpanjang terus,kalau ijin incenerator memang belum ada karena alatnya belum ada, ,tapi ke depan kita usahakan untuk mengurusnya karena salah satu penilaian dalam akreditasi nanti adalah perijinan IPAL dan incenerator ini sebagai syarat yang wajib di miliki oleh Rumah sakit (A)”

\section{Aspek Legalitas (perijinan, tenaga pengelola)}

Legalitas atau keabsahan rumah sakit merupakan hal mutlak yang wajib dimiliki oleh sebuah rumah sakit yang bekerja dengan BPJS Kesehatan sebagai syarat akreditasi. Ketidaklengkapan perizinan di RS TNI AL Samuel J. Moeda Kupang apabila di kaji dalam sisi perizinan rumah sakit, maka hal ini tidak sesuai dari aturan yang ada (Permenkes Nomor 147/Menkes/Per/I/2010 tentang Perizinan Rumah Sakit).

Regulasi lisensi untuk menjamin bahwa individu dan/atau lembaga pelayanan kesehatan tersebut telah memenuhi standar minimal untuk memenuhi standar politik dan tenaga kesehatan. Perizinan rumah sakit bertujuan untuk melindungi keselamatan masyarakat melalui peneraan standar input minimal yang harus dipenuhi . (Hikmatin, 2006). 
Manajemen tenaga pengelola limbah medis rumah sakit sesuai dengan Kepmenkes No. 1204 tahun 2004 yaitu harus dikepalai oleh kepala IPAL dengan latar belakang pendidikan dengan kualifikasi sanitarian. Hal ini sesuai dengan Kepmenkes No. 1204 tahun 2004 dimana penanggungjawab kesehatan lingkungan di RS kelas C dan D dan yang setingkat adalah tenaga yang memiliki kualifikasi sanitarian serendahrendahnya berijazah diploma (D3) di bidang kesehatan lingkungan.

Mergono (2006) dari hasil penelitian yang dilakukan ditemukan bahwa tenaga pengelola limbah medis sangat mempengaruhi pelaksanaan pengelolaan terhadap limbah, jika pendidikan yang di miliki tenaga pengelola tidak sesuai dengan standar yang ditetapkan maka akan berpengaruh terhadap hasil dari pelaksanaan pengelolaan limbah medis di rumah sakit tersebut. hal ini belum sesuai dengan Kepmenkes No. 1204 tahun 2004 dimana proses pengangkutan limbah medis padat dilakukan oleh tenaga pengelola di tambah latihan khusus. Hal ini membuat proses pengelolaan dan pemantauan terhadap limbah medis padat belum berjalan secara optimal.

\section{Aspek Input}

Aspek input dalam proses pengelolaan limbah medis padat terdiri dari tenaga pengelola, dana, dan sarana prasarana. Berdasarkan hasil wawancara ditemukan bahwa di RSAL belum ada tenaga dengan kualifikasi kesehatan lingkungan sebagai tenaga pengawak pengolahan limbah medis di rumah sakit. Disamping itu ditemukan bahwa tidak ada anggaran khusus untuk limbah medis, non medis maupun limbah cair serta fasilitas dan peralatan untuk pengelolaan limbah medis padat belum sesuai standar dan belum seluruhnya terpenuhi. Berikut kutipan wawancara kepala tata usaha RSAL Kupang :

“ Kalau untuk tenaga pengelola khusus dg kualifikasi sanitarian memang belum punya, kami mau merekrut juga susah karena anggaran terbatas, Kalau APD kita sih berusaha sesuai aturan tapi untuk semntara kami dukung yang penting - penting aja dulu seperti sarung tangan dg masker kedepan pelan - pelan kita sempurnakan”.(Informan B)

Manajemen tenaga pengelola limbah medis rumah sakit sesuai dengan Kepmenkes No. 1204 tahun 2004 yaitu harus dikepalai oleh kepala IPAL dengan latar belakang pendidikan dengan kualifikasi sanitarian D3 dan Petugas pengelola limbah seperti cleaning service yang harus berlatar pendidikan minimal SMP dan ditambah pelatihan khusus dan pengawasan pengelolaan limbah rumah sakit dilakukan oleh tenaga sanitasi dengan kualifikasi D1 ditambah latihan khusus. 
Pengelolaan limbah medis padat di RSAL tidak dikepalai oleh tenaga pengelola limbah medis yang sesuai tetapi dikelola oleh tenaga pengelola dengan latar belakang Analis Medis. Hal ini tidak sesuai dengan Kepmenkes No. 1204 tahun 2004 dimana penanggung jawab kesehatan lingkungan di RS kelas C dan D. Berdasarkan hasil penelitian yang dilakukan Mergono (2006) tenaga pengelola limbah medis sangat mempengaruhi pelaksanaan pengelolaan terhadap limbah, jika pendidikan yang dimiliki tenaga pengelola tidak sesuai dengan standar yang ditetapkan maka akan berpengaruh terhadap hasil dari pelaksanaan pengelolaan limbah medis di rumah sakit tersebut.

Hasil penelitian menunjukkan bahwa tidak ada anggaran di peroleh dari pusat APBN yang di turunkan ke Mabes TNI AL digunakan untuk semua faktor yang ada di rumah sakit dan dana yang dianggarkan tersebut sangat terbatas, sehingga tidak hanya digunakan pengelolaan limbah medis saja tetapi terbagi untuk faktor-faktor pengadaan bahan dan alat-alat medis lain yang mendapat perhatian lebih banyak. Adikoesumo (2003) mengatakan dana adalah rencana kerja yang dijabarkan dalam bentuk uang. Jadi dana merupakan rencana berisi ramalan pendapatan yang akan di terima serta pengeluaran yang terjadi pada tahun mendatang.

Hasil penelitian menunjukkan bahwa sarana prasarana pengelolaan limbah medis padat di RSAL belum semuanya tersedia dan belum memenuhi standar. Hal ini belum sesuai dengan Kepmenkes No. 1204 tahun 2004, dimana sarana prasarana pengelolaan limbah medis padat yang di maksud adalah tersedianya incenerator, oven, APD, tempat sampah, kantong plastik (hitam, merah, kuning dan coklat), TPS, autoclave, alat transportasi. Selain itu rumah sakit belum optimal dalam penyediaan 3 sarana prasarana penting dalam pengelolaan limbah medis padat yang terdiri dari oven, autoclave, dan incenerator. Selain itu, rumah sakit belum dilengkapi dengan TPS medis di rumah sakit sehingga ada limbah yang dibuang ke TPS umum di depan rumah sakit yang jaraknya lumayan jauh dari tiap ruang perawatan. Berdasarkan hasil penelitian dan kepustakaan dengan fasilitas yang dimiliki RS TNI AL Samuel J. Moeda Kupang belum memungkinkan untuk melakukan pengelolaan limbah medis padat yang sesuai dengan Kepmenkes No 1204 tahun 2004.

\section{Aspek Proses (Tata Laksanan Pengelolaan Limbah Medis)}

Hasil observasi kegiatan pemilihan/pemisahan limbah medis dan non medis di RS TNI AL Samuel J. Moeda, ditemukan hampir di setiap unit-unit perawatan masih banyak kesalahan saat pemisahan limbah medis sehingga banyak limbah yang tercampur antara limbah medis dan limbah non medis.Untuk pewadahan juga belum optimal, 
sebenarnya sudah sediakan wadah berupa tempat sampah fiberglass di setiap ruangan perawatan dan juga tempat sampah untuk pengunjung. Namun untuk jenis wadah kantong plastik di RS TNI AL Samuel J. Moeda belum terlengkapi semua jenisnya, sehingga pewadahan limbah medis di beberapa ruangan perawatan belum sesuai jenis kantong plastik yang seharusnya untuk limbah medis di lapisi dengan kantong plastik kuning dan limbah non medis dengan kantong plastik hitam.

Selain itu juga belum melakukan pemanfaatan kembali menggunakan autoclave untuk limbah medis padat. Sehingga rumah sakit hanya melakukan proses pemanfaatan kembali menggunakan oven dengan kapasitas minim dan hanya terbatas pada alat-alat medis pada OK dan UGD seperti pisau, gunting, scalpel, dan botol-botol laboratorium. Selain itu dalam proses pengumpulan limbah petugas cleaning service hanya menggunakan APD yang terbatas berupa handcsoon dan masker, yang kadang tidak digunakan padahal mereka harus bersentuhan langsung dengan limbah medis yang bisa menularkan penyakit seperti dari sisa-sisa darah, bekas infusan dan lain-lain. Ketersediaan petugas cleaning service yang kurang dan terbatas kadang membuat limbah medis di ruang perawatan bisa sampai menumpuk. Jadwal pengangkutan sampai pemusnahan limbah medis padat tidak di buat dalam bentuk jadwal kerja hanya di buat dalam bentuk absensi atau daftar hadir petugas cleaning service. . Pemusnahan limbah medis padat hanya secara manual atau melalui proses pembakaran biasa dan prosesnya dilakukan di lingkungan rumah sakit

"Ya jelas pernah. Coba kamu liat aja tiap hari di rawat inap. Sudah beberapa kali saya beritahukan, sudah diingatkan sampah itu ada 2 sampah medis dan sampah non medis. Tapi itu tadi kembali ke pribadi masing-masing itu hanya teori. Masa tiap hari saya harus triak-triak saya kan kerjaannya banyak, tidak hanya perawat saja. Jadi ya mohon maaf, tingkat kedisiplinannya kurang”.(Informan D)

Hasil penelitian menunjukkan bahwa pada tahap pemilihan antara jarum dengan limbah medis lain memang telah dipisahkan pada tempat khusus (Box Safety), namun untuk limbah medis padat lainnya dengan limbah non medis lain masih sering tercampur di unit-unit ruang perawatan ditemukan juga banyak limbah medis yang tercampur dengan limbah non medis di ruang perawatan dan beberapa poli. Paling banyak ditemukan limbah non medis yang tercampur dengan limbah medis seperti botol minuman, bungkusan nasi, tercampur dengan limbah medis seperti infusan, cateter, abocath. 
Proses pemilihan antara limbah medis padat yang tidak benar oleh petugas perawat dapat berakibat pada kecelakaan kerja petugas cleaning service yang akan melakukan pengangkutan dan pengumpulan limbah medis padat, karena limbah medis padat yang tercampur antara limbah infeksius maupun limbah benda tajam dan limbah lainnya dapat menimbulkan tertusuknya atau terpaparnya limbah medis infeksius terhadap petugas cleaning service.

Hasil penelitian ini menunjukkan bahwa manajemen pemilihan belum sesuai dengan Kepmenkes No. 1204 tahun 2014 dimana proses pemilihan/pemisahan dilakukan dari sumber penghasil limbah. Sedangkan berdasarkan hasil observasi menunjukkan bahwa pawadahan kantong plastik di unit penghasil limbah medis tidak sesuai dengan jenis limbah selain itu wadah untuk limbah medis yang harusnya menggunakan kantong plastik berwarna kuning tetapi yang di pakai yaitu kantong plastik berwarna putih selain itu limbah medis di beberapa ruangan tidak menggunakan kantong plastik sehingga langsung di buang di dalam ember tanpa label jenis limbah, untuk limbah infeksius yang harusnya di buang pada kantong plastik berwarna kuning tetapi pewadahannya digabungkan dengan kantong plastik untuk limbah medis padat lainnya. Hal ini disebabkan karena kelengkapan untuk pewadahan limbah medis tergantung pada anggaran yang ada karena anggaran dana yang disediakan tidak hanya terfokus pada limbah medis padat dan akan dilakukan pengadaan jenis pewadahan kantong plastik jika memang ada dana yang tersisa.

Untuk memudahkan pengosongan dan pengangkutan limbah medis padat penggunaan wadah kantong plastik pelapis dalam bak sampah sangat disarankan karena membantu membungkus limbah medis padat waktu pengangkutan sehingga mengurangi kontak langsung mikroba dengan manusia dan mengurangi bau (Depkes, 2002). Hal ini menunjukkan manajemen pewadahan di Rumah Sakit TNI AL Samuel J. Moeda Kupang belum sesuai dengan Kepmenkes dimana pewadahan limbah medis padat harus memenuhi persyaratan dengan penggunaan wadah kantong plastik sesuai kategori dan di beri pelabelan.

Hasil penelitian menunjukkan bahwa di R.S. TNI AL Samuel J. Moeda Kupang belum melakukan pemanfaatna kembali limbah dan alat medis padat secara baik dengan autoclave. Pihak rumah sakit hanya melakukan pemanfaatan kembali pada alat medis menggunakan alat oven yang hanya terbatas pada alat-alat yang dihasilkan di ruangan operasi dan IGD seperti pisau, gunting, scalpel, dan botol-botol laboratorium. Selain itu dari hasil observasi ditemukan bahwa proses sterilisasi dengan oven hanya di kelola dan 
diletakkan pada satu unit yaitu UGD dan lebih banyak melakukan proses sterilisasi pada unit UGD. Berdasarkan hasil wawancara diketahui bahwa ditemukan tindakan dari petugas cleaning service yang sebelumnya bekerja di rumah sakit, mengumpulkan sisa limbah medis seperti botol infuse untuk di jual kepada pengumpul. Ini sangat bertentangan dengan peraturan yang ada. Menurut WHO (1999) petugas yang mengumpulkan limbah tidak boleh untuk mencoba memisahkan limbah dari kontainer atau plastik sebelum dilakukan pemusnahan, hal ini terjadi membuka kesempatan untuk terjadinya penyebaran penyakit.

Proses pemanfaatan kembali oleh Rumah Sakit TNI AL Samuel J. Moeda Kupang ini tidak sesuai dengan aturan Kepmenkes 1204 tahun 2004. Pengumpulan limbah medis yaitu mengambil limbah medis dari bak sampah yang berada di setiap ruangan penghasil limbah medis ke titik pengumpul sementara yang sudah ditentukan sesuai dengan aturan Kepmenkes No. 1204 tahun 2004 Pengumpulan limbah medis padat merupakan kegiatan yang beresiko terhadap keselamatan dan kesehatan pekerja apabila tidak menggunakan APD lengkap dan tidak dibekali dengan pelatihan karena pelatihan pekerja, penggunaan APD, dan imunisasi hepatitis sangat diperlukan bagi orang yang beresiko dalam menangani limbah medis padat terutama petugas kebersihan (Rushbrook, 2005).

Pengolahan dan pemusnahan limbah medis padat yang sesuai dengan Kepmenkes No. 1204 tahun 2004 yaitu menggunakan incenerator. Hasil penelitian menunjukkan bahwa proses manajemen pengolahan dan pemusnahan limbah medis padat di Rumah Sakit TNI AL Samuel J. Moeda Kupang masih dilakukan secara manual dikarenakan belum memiliki Incenerator. Selain itu, sebelum dilakukan pembakaran limbah medis petugas cleaning service tidak melakukan proses pemilihan ulang sehingga ditemukan pencampuran antara limbah medis dengan kertas-kertas, plastik, dan botol minuman. Dari hasil observasi pada proses pembakaran limbah medis, petugas cleaning service tidak diawasi oleh petugas pengawas dari bagian sanitasi di saat petugas cleaning service harus bersentuhan dengan limbah-limbah benda tajam dan infeksius yang memungkinkan terjadinya penularan penyakit dan kecelakaan saat bekerja.

\section{Aspek Output}

Hasil penelitian menunjukkan bahwa pengelolaan limbah medis padat di RS TNI AL belum sesuai aturan dibuktikan dari hasil akhir pengelolaan limbah tidak terselesaikan hingga tuntas, dimana masih terdapat sisa-sisa limbah yang tidak dapat hancur menjadi abu seperti botol kaca atau ampul dan sisa-sisa jarum suntik sebagaimana bila pemusnahan menggunakan incenerator. 
Kemudian sisa-sisa limbah medis padat yang tidak habis terbakar tersebut hanya di buang pada TPS umum yang tersedia di depan rumah sakit, jika pada lubang septic tank telah penuh. Berdasarkan Kepmenkes No. 1204 Tahun 2004 yaitu cara dan teknologi pengelolaan atau pemusnahan limbah medis padat disesuaikan dengan kemampuan rumah sakit dan jenis limbah medis padat yang ada dengan pemanasan menggunakan autoclave dan dengan pembakaran menggunakan incenerator. Sedangkan dari hasil penelitian di RS TNI AL belum menggunakan sterilisasi autoclave pada bahan dan limbah medis padat, sehingga pada sterilisasi alat medis hanya menggunakan oven dan pada limbah medis padat belum dilakukan sterilisasi untuk membunuh mikroorganisme yang seharusnya bisa dilakukan menggunakan autoclave sebelum dimusnahkan dengan incenerator.

\section{PENUTUP}

\section{Simpulan}

Berdasarkan hasil penelitian mengenai Manjemen Pengelolaan limbah medis padat di R.S TNI AL Samuel J. Moeda Kupang dapat disimpulkan bahwa:

1) Manajemen pengolahan limbah medis Aspek legalitas yaitu belum dilakukannya pemeriksaan sampel air limbah secara berkala, belum adanya standar SOP serta belum adanya ijin incenerator karena alatnya belum tersedia

2) Manajemen pengelolaan limbah medis di R.S TNI AL Samuel J. Moeda dari aspek input belum sesuai standar Kepmenkes No. 1204 tahun 2004, dimana belum tersedia tiga instrument penting dalam pengelolaan limbah medis padat yaitu incenerator, autoclave dan oven.

3) Manajemen pengelolaan limbah medis di R.S TNI AL Samuel J. Moeda dari aspek proses yaitu pemilihan, pewadahan, penyimpanan sementara, pemanfaatan kembali dan pemusnahan belum sesuai standar Kepmenkes No. 1204 tahun 2004, dimana proses masih dilakukan secara manual dan seadanya.

4) Manajemen pengelolaan limbah medis di R.S TNI AL Samuel J. Moeda dari aspek output belum terkelola dengan baik karena belum sesuai standar Kepmenkes No. 1204 tahun 2004, dimana hasil akhir limbah medis padat belum berakhir dengan baik dan masih berupa sisa-sisa limbah medis padat.

5) Manajemen minimisasi dengan pemamfaatan kembali untuk limbah medis belum dimamfaatkan dengan baik untuk untuk mengurangi produksi limbah medis di Rumah sakit. 


\section{DAFTAR PUSTAKA}

Adisasmito, W. (2007). Sistem Manajemen Lingkungan Rumah Sakit. Jakarta: Grafindo Persada.

Azwar, A. (1996). Menjaga Mutu Pelayanan Kesehatan. Jakarta: Sinar Harapan.

Bapedal. (1992). Pedoman Minimisasi Limbah. Jakarta: Bapedal.

CDC. (2003). Guidelines for Environmental Infection Control in Health Cre Facilities. Atlanta: Center for Disease Control and Prevention.

olony, S. (2001). Hospital Waste Management at SMF. 10 Oktober 2011. http://www.SMF-Hospital waste management.htm

Comba, P., et al. (2007). Risk of Soft Tissue Sarcomas and Residence in the Neighbourhood of an Incinerator of Industrial Wastes. Occupational and

Departemen Kesehatan RI. (2002). Pedoman Sanitasi Rumah Sakit di Indonesia.

Departemen Kesehatan RI. (2006). Pedoman Pelaksanaan Pengelolaan Limbah

Padat dan Limbah Cair di Rumah Sakit. Jakarta: Direktorat Jenderal PPM \& PPL dan Direktorat Jenderal Pelayanan Medik.

Ditjen PP\& PL. (20-22 Oktober 2011). Kebijakan Kesehatan Lingkungan Dalam Pengelolaan Limbah Medis di Fasyankes. Jakarta: Direktorat PL.

Hapsari, R. (2010). Analisis Pengelolaan Sampah Dengan Pendekatan Sistem di RSUD DR Moewardi Surakarta. Tesis, Program Pascasarjana. Semarang: Universitas Diponegoro.

Kementerian Negara Lingkungan Hidup. Pengelolaan Bahan dan Limbah Berbahaya dan Beracun. (2006). Limbah Rumah Sakit. 6 Oktober 2011. http://b3.menlh.go.id/pengelolaan/article.php?article id=95

Kepmenkes Nomor 1204/Menkes/SK/X/2004 tentang Persyaratan Kesehatan Lingkungan Rumah Sakit. Jakarta: Direktorat Penyehatan Lingkungan.

Peraturan Pemerintah No. 74 tahun 2001 tentang Pengelolaan Bahan Berbahaya dan Beracun.

Perdani, I.P. (2011). Identifikasi Penyebaran Limbah Padat B3 dari Fasilitas Kesehatan di Surabaya Timur. Skripsi. Surabaya: ITS.

Peraturan Menteri Kesehatan. No. 340/Menkes/Per/III/2010 Tentang Klasifikasi Rumah Sakit.

Rakhmaniar, D. (2006). Pengelolaan Sampah medis Infeksius di PT. Rumah Sakit Port Health Center Surabaya. Tesis. Surabaya: Universitas Airlangga.

Rau, E.R., et al. (2000). Minimization and Management of Wastes from Biomedical Research. Environmental Health Perspectives, 6, 108. Reinhardt, P. A. \& Gordon, J. G. (1995). Infectious and Medical Waste Management. USA: Lewish Publisher Inc. Michigan.

Suryandari, Siswantini. (2010, Agustus 6). Pengolahan Limbah Medis belum Berstandar. Media Indonesia, p. 20 U.S Departement of Health and Human Service. (2011). Dialyzer Germicides. 12 Desember 2011. http://www.fda.gov/MedicalDevices/Safety.htm

Wisaksono, S. (2001). Karakteristik Limbah Rumah Sakit dan Pengaruhnya terhadap Kesehatan dan Lingkungan. (Edisi Cermin Dunia Kedokteran No. 130). Jakarta: Depkes RI. 